\title{
A Nationwide Cross-Sectional Study of Self-Reported Adherence and Factors Associated with Analgesic Treatment in People with Chronic Pain
}

\author{
Patricia Ortega-Jiménez ${ }^{1,2}$, Helena De Sola ${ }^{1,3,4, *(\mathbb{D})}$, Alejandro Salazar $1,2,4$ (D), \\ María Dueñas ${ }^{1,2,4} \mathbb{D}_{\text {, Leticia Del Reguero }}{ }^{1}$ and Inmaculada Failde ${ }^{1,3,4}$ (D) \\ 1 The Observatory of Pain, University of Cádiz, 11009 Cádiz, Spain; patricia.ortega@uca.es (P.O.-J.); \\ alejandro.salazar@uca.es (A.S.); maria.duenasro@uca.es (M.D.); leticiadelreguero@gmail.com (L.D.R.); \\ inmaculada.failde@uca.es (I.F.) \\ Department of Statistics and Operational Research, University of Cádiz, 11510 Puerto Real, Spain \\ Preventive Medicine and Public Health Area, University of Cádiz, 11009 Cádiz, Spain \\ 4 Biomedical Research and Innovation Institute of Cádiz (INiBICA), 11009 Cádiz, Spain \\ * Correspondence: Helena.desolaperea@alum.uca.es; Tel.: +34-956-019-086
}

Received: 19 October 2020; Accepted: 12 November 2020; Published: 14 November 2020

\begin{abstract}
This study aims to shed light on the frequency and associated factors of self-reported adherence to analgesic treatment among chronic pain (CP) patients in the Spanish population. A nationwide cross-sectional study was performed of 1066 Spanish adults, of whom 251 suffered from $\mathrm{CP}$ and 168 had been prescribed analgesic treatment. Adherence was assessed using a self-reported direct questionnaire and related factors were collected. Descriptive and bivariate analyses were conducted. Among the $23.5 \%$ (95\% CI: $21.0-26.2 \%$ ) of the sample with CP, $66.9 \%$ (95\% CI: $60.7-72.7 \%$ ) were taking analgesic treatment prescribed by a doctor, and $81.0 \%$ (95\% CI: $74.2-86.6 \%$ ) said they took the treatment as the doctor indicated. However, $17.6 \%$ forgot to take the medication, $11 \%$ overused them when in great pain, $46.3 \%$ stopped the treatment when feeling better and $33.3 \%$ when feeling worse, and $7.3 \%$ stopped taking them for financial reasons. Higher intensity of pain, polymedication, administration route (injection/patches) and some patient-related factors were associated with self-perceived adherence to treatment. Most Spanish people with CP consider that they are adherent to their analgesic treatment. However, their behavior presents contradictions. It would be advisable for professionals to inform patients about appropriate behavior regarding their therapy recommendations, and to explore potential factors related to non-adherence. This could contribute to improving pain control.
\end{abstract}

Keywords: adherence; chronic pain; analgesic treatment; cross-sectional study

\section{Introduction}

Chronic pain (CP) is a major public health problem, recognized as a chronic disease entity [1], that affects between $10 \%$ and $30 \%$ of the adult population in Europe [2,3] and around $17 \%$ of the Spanish population [4]. The pain experience also has great impact on the physical and mental health of the patients, and on their working, family and social lives, leading to a heavy burden on the healthcare system [5-7].

Despite its relevance and the availability of treatments for pain relief, the management of $\mathrm{CP}$ needs to be improved [8]. In Spain, as in other countries such as Portugal or Norway [9-11], pain control is far from optimal, as $35 \%$ of CP patients taking treatment still refer to severe pain [6,8]. Several barriers have been related to pain control, associated with a lack of time for patient care, poor coordination 
between units involved in the management of these patients, poor communication between healthcare professionals or limited availability of specialized services [8].

Despite these barriers, pharmacological therapy is the most common way of dealing with pain, and adherence to the treatment is therefore considered an important factor in achieving this aim [12,13]. Adherence to treatments among people with $\mathrm{CP}$ has been shown to be inconsistent [13], ranging from $8-62 \%$. This variability has been associated not only with the different terminology used to define the adherence concept, but also with the methods used for its assessment, making it difficult to compare results between studies and apply them in clinical practice [14].

Adherence to medication can be affected by a variety of demographic, clinical or socioeconomic factors [15]. The World Health Organization (WHO) has classified these factors into five dimensions: those related to socioeconomic conditions, since a low socioeconomic status may put patients in the position of having to choose between priorities; those associated with the pathology, such as the severity of the disease (physical, psychological) or patients' perception of risk; those related to the treatments (complexity of the treatment, duration of treatment, beneficial effects, side effects, etc.); characteristics of the patients (forgetfulness, beliefs, perceptions, etc.); and those related to the health system and its professionals, given that a good patient-provider relationship may improve adherence, and many factors such as lack of knowledge or lack of feedback on performance could have a negative effect [16]. The analysis and identification of obstacles related to these factors could contribute to improving both adherence and patients' health outcomes.

Additionally, it has been shown [17] that a lack of adherence among patients may be either intentional or unintentional. Non-adherence is considered unintentional when a patient is unable to adhere with medical recommendations because of lack of capacity or resources, such as low health literacy. Meanwhile, intentional non-adherence refers to an active decision of the patient to not adhere to their physician's instructions, which can be influenced, among other matters, by individual perceptions about the disease [17].

In Spain, several studies have investigated the adherence to analgesic therapy in the $\mathrm{CP}$ population $[2,18]$ but, to the best of our knowledge, none have analyzed the adherence to medication in the context of the five dimensions defined by the WHO. Thus, we carried out this study, the main objective of which was to ascertain the frequency of self-reported adherence to analgesic treatment among the general Spanish population with $\mathrm{CP}$, and to analyze the socioeconomic, health care, treatment, pathology and patient characteristics related to adherence to medication.

\section{Materials and Methods}

\subsection{Participants and Recruitment}

A nationwide epidemiological cross-sectional study was carried out on a representative sample of the general Spanish population, with the target population including individuals in households with a landline telephone. The target population included people $\geq 18$ years old living at the household selected who agreed to participate in the study and were able to complete the questionnaire. The exclusion criteria were: age $<18$ years old, a nationality other than Spanish, not living at the selected address, no landline telephone in the house, cancer pain or any inability to respond to the questionnaire.

\subsection{Sampling Methods}

A multistage stratified sampling method was carried out in three phases. In the first, the Spanish territory was divided into 8 strata based on geographical and historical boundaries and according to an aging criterion based on the ratio between people over 65 and under 15 years old, as seen in [19]. For each stratum, a number of municipalities were randomly selected proportional to the stratum weight in the total population, considering the Spanish rural $(<10,000$ inhabitants)/urban $(>10,000)$ ratio of 25:75. A total of 20 municipalities were chosen. This division was considered as it has been shown that "aging" and "geographic zone" are factors that influence chronic pain prevalence [20-24]. 
In the second phase, sampling units (telephone numbers) from each town were selected from the list of telephone numbers included in the Infobel España Office v.7.1 directory ${ }^{\circledR}$ (Kapitol S.A, Brussels, Belgium) by simple random sampling, until the quota of each stratum was fulfilled. This directory includes the telephone numbers of $90 \%$ of all Spanish households [25] with a landline telephone and, considering that $80.6 \%$ of Spanish households have one [26], we had access to $72.5 \%$ of the eligible Spanish population.

In the third phase, the number of subjects was divided into 6 strata according to the sex and age distribution of the population: male aged 18-44; female aged 18-44; male aged 45-64; female aged 45-64; male aged $\geq 65$; and female aged $\geq 65$. In each of the municipalities, quotas were established, taking into account sex and age based on data on the Spanish population [27]. The subjects interviewed from the households were randomly selected according to the previously established sex and age quotas, and they were distributed in proportion to the size of each previously selected municipality. Within the household, the criteria were to select the first person who replied, as long as the quota of their stratum was not completed. In the event that the quota was completed, the selection of the other person of the household was established in the following order: men 18-44 years old; women 18-44 years old; men over 65 years old; women over 65 years old; men $45-64$ years old; women $45-65$ years old. The order was established according to the difficulty in filling each quota.

\subsection{Sample Size}

The sample size was calculated, bearing in mind the results obtained from a pilot study previously carried out by the authors, where the prevalence of $\mathrm{CP}$ was around $22 \%$, and $67 \%$ of the subjects with $\mathrm{CP}$ were under analgesic treatment, and based on previous reports of adherence prevalence in Spain of $45.34 \%$ [2].

Thus, considering a confidence level of $95 \%$ and a precision of $8 \%$, the required sample size was established at 1014 subjects. The sample size was finally adjusted upwards to 1066 subjects, as a preventive measure for missing data.

\subsection{Procedure and Instruments}

From February to June 2017, data were collected between 4 p.m. and 8 p.m. from Monday to Friday using a computer-assisted telephone interview, and the Skype ${ }^{\circledR}$ (Skype Communications SARL, Luxembourg) and SurveyMonkey ${ }^{\circledR}$ platforms (SurveyMonkey Europe UC, Dublin, Ireland). Previously, the interviewers received a $10 \mathrm{~h}$ workshop in which they were trained in the purpose of the study, the working protocol and the use of the SurveyMonkey ${ }^{\circledR}$ platform. Furthermore, a pilot test was conducted during the previous week to analyze the comprehensibility and acceptability of the questionnaire and to detect and correct any potential problems related to the questions and the data collection procedure.

The collection of data was coordinated and supervised on a daily basis by a member of the research team, addressing any problems that had arisen.

\subsection{Ethical Statement}

Participation in the study was voluntary. All subjects included in the study were informed of the purpose and design of the research, and reassured that their identities and answers to the questionnaire were confidential. The subjects were informed of their right to withdraw from the interview at any moment. All subjects gave their oral consent for inclusion before they participated in the study. The study was conducted in accordance with the Helsinki Declaration and following standard working procedures. The study was approved by the Clinical Research Ethics Committee of Cádiz (Spain) (ASC-DC-2018), which declares and certifies that this project is viable, has sufficient methodological rigor and a correct assessment of the economic cost, and complies with the necessary requirements regarding the suitability of the protocol in terms of the aims of the study. 


\subsection{Survey Structure}

The survey was structured in 5 blocks, taking into account the factors defined by The World Health Organization (WHO) [16]. The first block was designed to obtain sociodemographic information such as age, sex, educational level, employment status or financial difficulties, assessed by asking about the difficulties found making ends meet each month. This block also contained a question used to identify subjects with CP. Accordingly, a subject was considered to suffer from CP if they had experienced pain (at least 4 days a week) over the last 3 months, in accordance with the International Association for the study of Pain (IASP) definition [28].

In the second block of the survey, dealing with $\mathrm{CP}$, the subjects were asked about condition-related factors, such as diagnoses, duration and pain intensity, and about the presence of other physical comorbidities. Pain intensity was measured on a numerical rating scale (0-10), where higher scores represented more intense pain, and grouped into three categories to facilitate the analysis: "mild" (1-3), "moderate" (4-6), "severe" (7-10) [29,30]. The presence of depression and anxiety was also assessed, using the questions: "Have you suffered from depression (or anxiety) during the previous 12 months?" and "Has your medical doctor confirmed the diagnosis?" [19]. A patient was considered to have diagnosed depression (or anxiety) if both answers were affirmative.

The third block started with a screening question to identify those people with $\mathrm{CP}$ taking analgesic treatment prescribed by a doctor. From this question, and until the end of the interview, only people with $\mathrm{CP}$ that had been prescribed analgesic treatment were considered. For the purposes of this study, adherence to analgesic medication was measured in this block using the self-reported direct question (SRDQ) "Do you take your prescription as the doctor indicated?" When the answer to this question was negative, two questions were asked "Do you take more?" and "Do you take less?" In this block, information was also collected about factors related to the treatment, such as duration of the treatment, type and route of the treatment administration and about expectations of improvement, opinions of the pain treatment, addiction and side effects related to analgesic therapy.

The fourth block of the questionnaire included patient-related factors, such as forgetfulness, "Do you ever forget to take your pain medicine?", questions related with the behavior of the patient "If you ever feel more pain, do you take more medicine than prescribed?", "Have you ever stopped taking medication due to its price or skipped doses so drugs last longer?" and the perception of their health status.

Finally, with the fifth block we explored healthcare professional- and family-related factors such as opinions of the respondent about the information and attention received from their doctor and family.

\subsection{Statistical Analysis}

A descriptive analysis was performed, using measures of frequency (absolute and relative), central tendency (mean) and dispersion (standard deviation). To check the normality in the distribution of the quantitative variables, the Kolmogorov-Smirnov test was used. To analyze the associations between variables, $\chi^{2}$ tests were used for the qualitative variables, and the Mann-Whitney U test for quantitative variables. The threshold for significance was set at $p=0.05$.

These analyses were all carried out with the IBM SPSS Statistics $22^{\circledR}$ (IBM Corporation, Armonk, NY, USA) statistical package.

\section{Results}

\subsection{Characteristics of the Sample}

Of the 3586 people contacted, 1092 were interviewed, and a response rate of $30.5 \%$ was achieved. The main reason for refusing to participate was "I do not have time" (42.2\%), followed by "I am not interested in the topic" $(29.2 \%)$. In $23.1 \%$ of the cases, no reason for refusal was given (Figure 1 ). Additionally, 26 subjects were excluded because of missing information about their sex or age. Therefore, 
the final number of subjects included in the study was 1066 . The characteristics of the total sample are shown in Table 1.

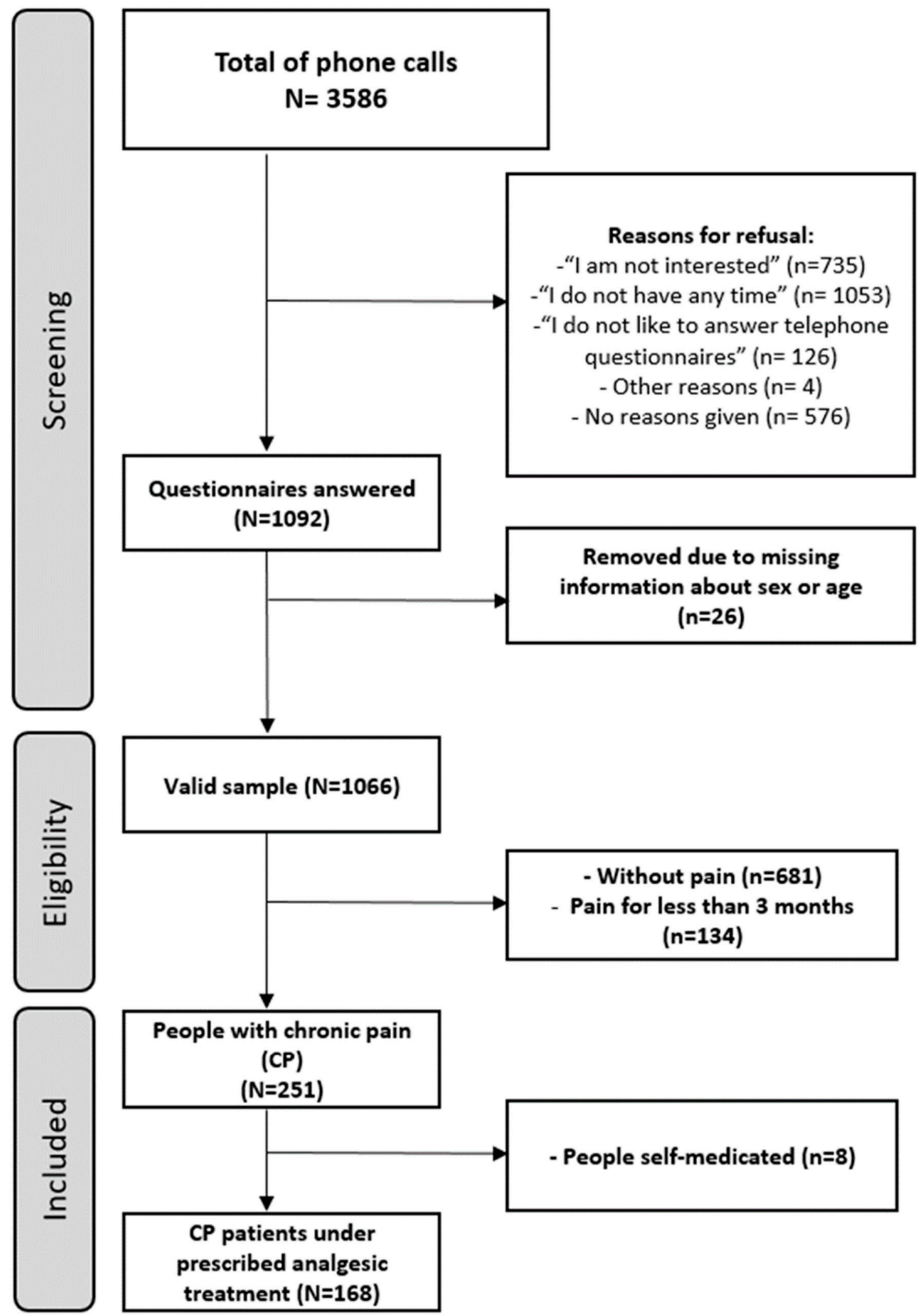

Figure 1. Flowchart of the sample.

Of the participants, 251 subjects (23.5\%; $95 \%$ CI: $21.0-26.2 \%)$ referred to CP; $68.9 \%$ were women and the mean age was $55.9(\mathrm{SD}=15.5)$. Pain intensity $\geq 7$ was reported by $54.9 \%$, and the mean 
duration of pain was nearly nine years (105.92 months, $\mathrm{SD}=125.45 ;$ median $=60$ months), back, neck or shoulder pain being the most frequent cause (30\%), followed by arthritis (23\%) (Figure 2).

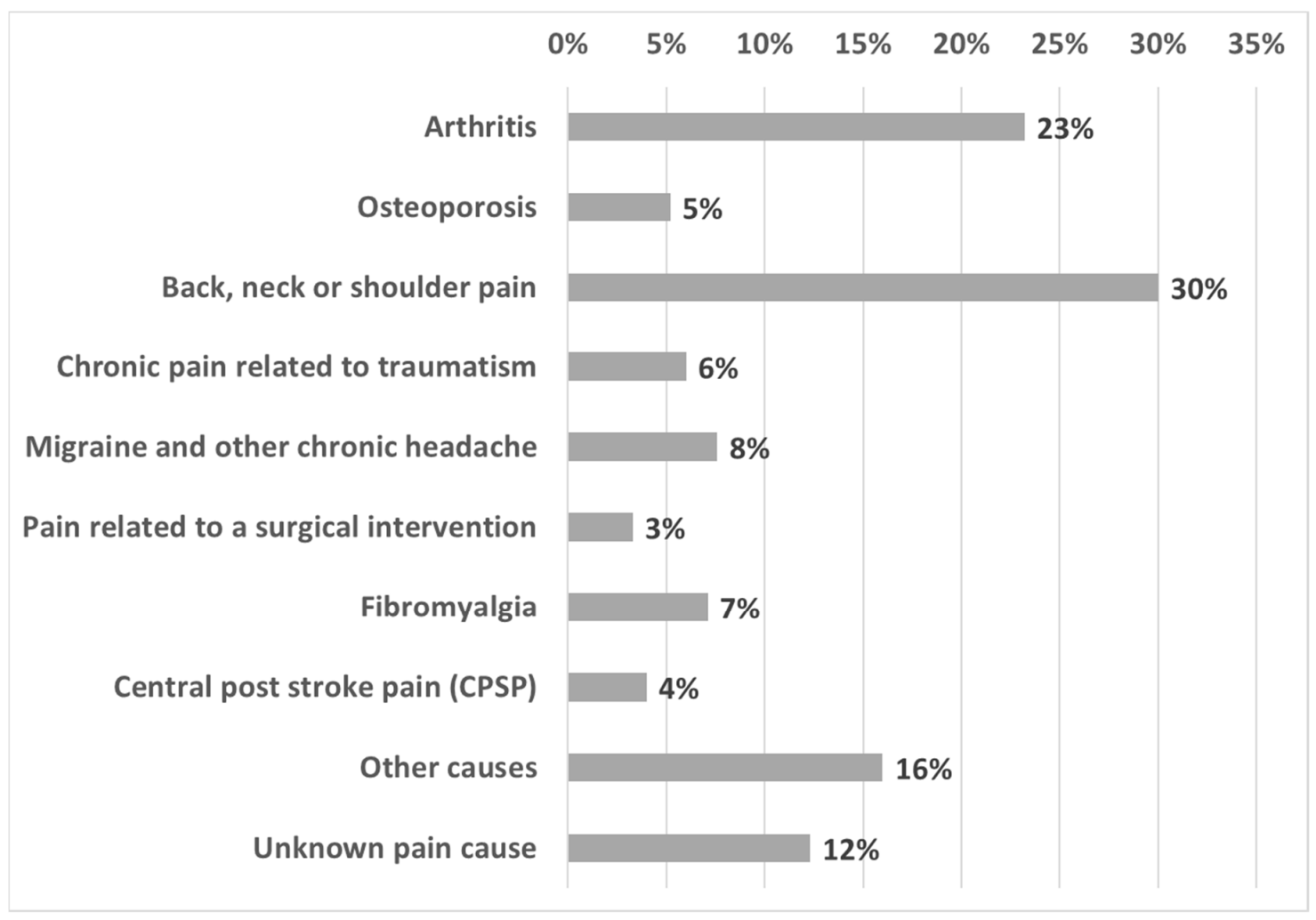

Figure 2. Pain diagnosis $(n=251)$.

Table 1. Characteristics of the sample.

\begin{tabular}{|c|c|c|c|c|}
\hline Variables & Categories & $\begin{array}{l}\text { Whole Sample } \\
\qquad \begin{array}{c}n=1066) \\
n(\%)\end{array}\end{array}$ & $\begin{array}{c}\text { People with Chronic } \\
\text { Pain (CP) }(n=251) \\
n(\%)\end{array}$ & $\begin{array}{c}\text { People with CP Taking } \\
\text { Analgesic Treatment }(n=168) \\
n(\%)\end{array}$ \\
\hline \multicolumn{5}{|c|}{ SOCIODEMOGRAPHIC DATA } \\
\hline \multirow{3}{*}{ Age } & $18-44$ & $424(39.8)$ & $72(28.7)$ & $45(26.8)$ \\
\hline & $45-64$ & $385(36.1)$ & $105(41.8)$ & $68(40.5)$ \\
\hline & 65 or more & $257(24.1)$ & $74(29.5)$ & $55(32.7)$ \\
\hline Age & Mean (SD) & $51.6(16.5)$ & $55.9(15.5)$ & $57.1(15.6)$ \\
\hline \multirow{2}{*}{ Sex } & Men & $456(42.8)$ & $78(31.1)$ & $40(23.8)$ \\
\hline & Women & $610(57.2)$ & $173(68.9)$ & $128(76.2)$ \\
\hline \multirow{5}{*}{ Education level } & No education received & $83(7.8)$ & $31(12.4)$ & $21(12.5)$ \\
\hline & Primary school & $215(20.3)$ & $73(29.1)$ & $49(29.2)$ \\
\hline & Secondary school & $252(23.8)$ & $54(21.5)$ & $37(22)$ \\
\hline & Vocational training & $162(15.3)$ & $42(16.7)$ & $29(17.3)$ \\
\hline & University degree & $348(32.8)$ & $51(20.3)$ & $32(19)$ \\
\hline \multirow{7}{*}{$\begin{array}{l}\text { Employment } \\
\text { status }\end{array}$} & Unemployed & $147(13.8)$ & $41(16.4)$ & $29(17.4)$ \\
\hline & Student & $54(5.1)$ & $4(1.6)$ & $3(1.8)$ \\
\hline & Housewife/househusband & $125(11.8)$ & $43(17.2)$ & $34(20.4)$ \\
\hline & Working & $484(45.6)$ & $92(36.8)$ & $57(34.1)$ \\
\hline & Retired & $240(22.6)$ & $60(24)$ & $39(23.4)$ \\
\hline & Partial disability & $6(0.6)$ & $5(2)$ & $2(1.2)$ \\
\hline & Total disability & $6(0.6)$ & $5(2)$ & $3(1.8)$ \\
\hline \multirow{6}{*}{$\begin{array}{l}\text { Financial } \\
\text { difficulties }\end{array}$} & With great difficulty & $65(6.2)$ & $30(12)$ & $20(12)$ \\
\hline & With difficulty & $137(13)$ & $45(18.1)$ & $29(17.4)$ \\
\hline & With some difficulty & $201(19.1)$ & $60(24.1)$ & $40(24)$ \\
\hline & With some ease & $272(25.9)$ & $59(23.7)$ & $45(26.9)$ \\
\hline & With ease & $339(32.3)$ & $53(21.3)$ & $32(19.2)$ \\
\hline & With great ease & $37(3.5)$ & $2(0.8)$ & $1(0.6)$ \\
\hline
\end{tabular}


Among the people with CP, 66.9\% (95\% CI: 60.7-72.7\%) were taking analgesic treatment prescribed by a doctor $(n=168)$, and $3.2 \%(n=8)$ were self-medicated. In the group taking treatment, $76.2 \%$ were women, the mean age was $57.1(\mathrm{SD}=15.6)$, only $34.1 \%$ were working and $53.4 \%$ had financial difficulties (Table 1). The average pain intensity of the people with CP taking analgesic treatment was over 7 points, and the duration of the pain was more than 10 years.

\subsection{Comparison of the Factors Related to Self-Reported Adherence among People with CP Taking Treatment}

The findings of the study show that $81 \%$ (95\% CI: 74.2-86.6\%) of the sample claimed to take the treatment as the doctor indicated (self-reported adherence), and only 19\% self-reported not doing so.

In the comparison between both groups, we found that the sociodemographic and economic factors were similar. However, in the self-reported adherent group, there were more subjects that were inactive, retired or housewives/husbands than in the non-adherent group (Table 2).

Regarding the condition-related factors, we observed that people who self-reported being adherent had a higher intensity of pain, and the main causes of pain were migraine and osteoporosis. Nevertheless, the duration of pain and the presence of comorbidities such as anxiety or depression were similar in both groups (Table 2).

With regard to the therapy-related factors, the self-reporting adherence group reported more frequently taking more than one medication $(81.7 \%$ vs. $57.7 \%)$, taking benzodiazepines and using more drugs parenterally or in patches than the non-adherent group. No differences between the two groups were observed in the opinion on side effects, the addiction associated with pain relief medications, the duration of the treatments or the expectations regarding them. (Table 2).

Table 2. Comparison of the factors related to self-reported adherence among people with chronic pain taking treatment.

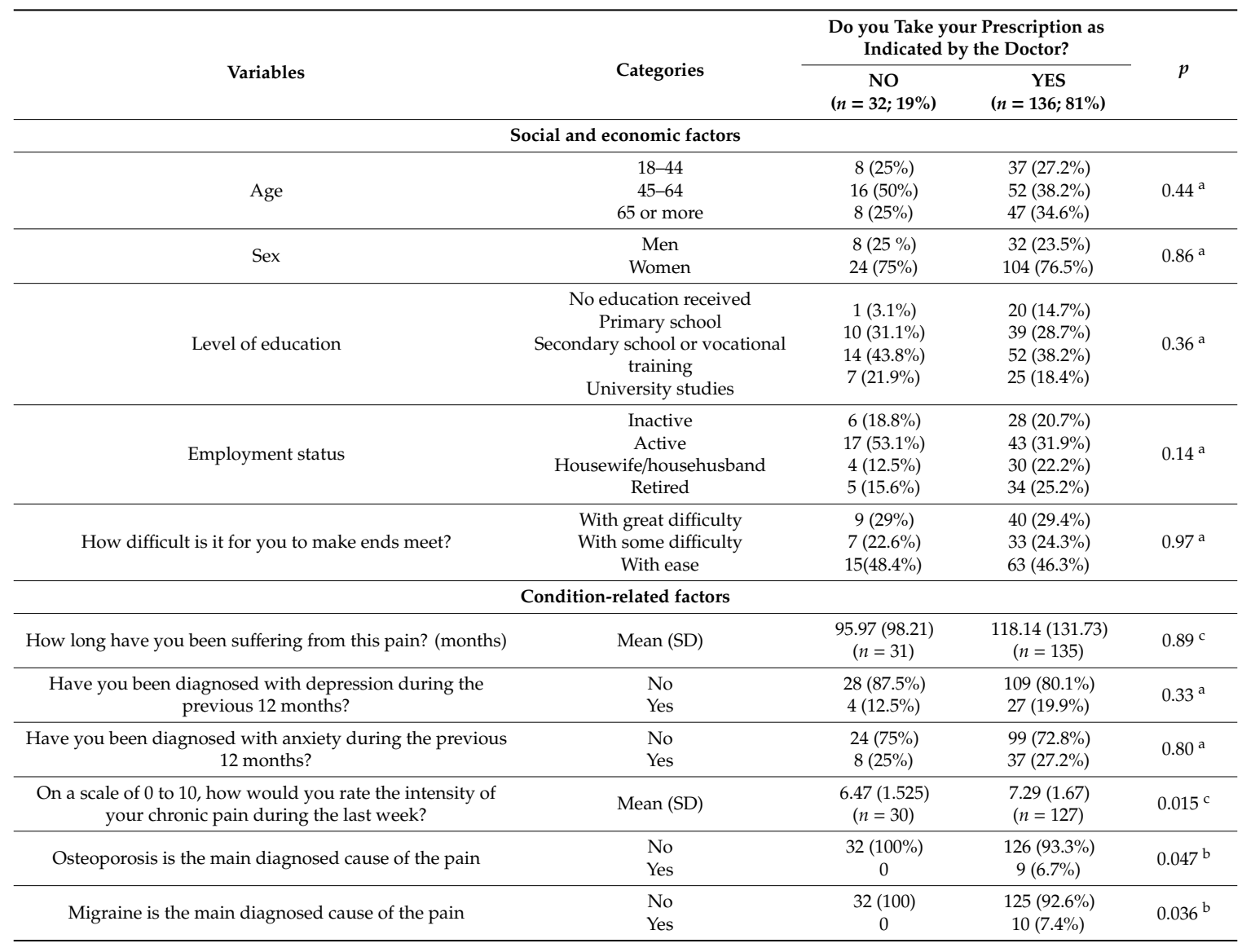


Table 2. Cont.

\begin{tabular}{|c|c|c|c|c|c|}
\hline \multirow{2}{*}{\multicolumn{2}{|c|}{ Variables }} & \multirow[b]{2}{*}{ Categories } & \multicolumn{2}{|c|}{$\begin{array}{l}\text { Do you Take your Prescription as } \\
\text { Indicated by the Doctor? }\end{array}$} & \multirow[b]{2}{*}{$p$} \\
\hline & & & $\begin{array}{c}\mathrm{NO} \\
(n=32 ; 19 \%)\end{array}$ & $\begin{array}{c}\text { YES } \\
(n=136 ; 81 \%)\end{array}$ & \\
\hline \multicolumn{6}{|c|}{ Therapy-related factors } \\
\hline \multicolumn{2}{|c|}{$\begin{array}{l}\text { How long have you been taking the pain medication? } \\
\text { (months) }\end{array}$} & Mean (SD) & $\begin{array}{l}79.52(93.75) \\
(n=29)\end{array}$ & $\begin{array}{l}89.91(117) \\
(n=124)\end{array}$ & $0.874^{\mathrm{c}}$ \\
\hline \multirow{6}{*}{$\begin{array}{l}\text { Could you tell me which } \\
\text { medication you have been } \\
\text { prescribed for the pain? }\end{array}$} & NSAIDs (M01A) & $\begin{array}{l}\text { No } \\
\text { Yes }\end{array}$ & $\begin{array}{l}10(37.0 \%) \\
17(63.0 \%)\end{array}$ & $\begin{array}{l}58(48.3 \%) \\
62(51.7 \%)\end{array}$ & $0.287^{a}$ \\
\hline & $\begin{array}{l}\text { Antipyretic analgesics } \\
\text { (N02B) }\end{array}$ & $\begin{array}{l}\text { No } \\
\text { Yes }\end{array}$ & $\begin{array}{l}14(51.9 \%) \\
13(48.1 \%)\end{array}$ & $\begin{array}{l}72(60.0 \%) \\
48(40.0 \%)\end{array}$ & $0.44^{\mathrm{a}}$ \\
\hline & Opioids (N02A) & $\begin{array}{l}\text { No } \\
\text { Yes }\end{array}$ & $\begin{array}{c}24(88.9 \%) \\
3(11.1 \%)\end{array}$ & $\begin{array}{l}89(74.2 \%) \\
31(25.8 \%)\end{array}$ & $0.10^{\mathrm{a}}$ \\
\hline & Antidepressant (N06A) & $\begin{array}{l}\text { No } \\
\text { Yes }\end{array}$ & $\begin{array}{c}26(96.3 \%) \\
1(3.7 \%)\end{array}$ & $\begin{array}{l}114(95.0 \%) \\
6(5.0 \%)\end{array}$ & $0.77^{b}$ \\
\hline & Antiepileptic (N03A) & $\begin{array}{l}\text { No } \\
\text { Yes }\end{array}$ & $\begin{array}{l}26(96.3 \%) \\
1(3.7 \%)\end{array}$ & $\begin{array}{l}111(92.5 \%) \\
9(7.5 \%)\end{array}$ & $0.45^{b}$ \\
\hline & $\begin{array}{l}\text { Others (benzodiazepines, } \\
\text { cortisone, etc.) }\end{array}$ & $\begin{array}{l}\text { No } \\
\text { Yes }\end{array}$ & $\begin{array}{c}27(100 \%) \\
0(0 \%)\end{array}$ & $\begin{array}{l}98(81.7 \%) \\
22(18.3 \%)\end{array}$ & $0.002^{b}$ \\
\hline \multicolumn{2}{|c|}{$\begin{array}{l}\text { How many medications are you taking in total at the } \\
\text { moment (not just for the pain)? }\end{array}$} & $\begin{array}{c}\text { One } \\
\text { Two or three } \\
\text { Four or five } \\
\text { More than five }\end{array}$ & $\begin{array}{c}13(43.3 \%) \\
12(40 \%) \\
4(13.3 \%) \\
1(3.3 \%)\end{array}$ & $\begin{array}{c}26(19.3 \%) \\
59(43.7 \%) \\
23(17 \%) \\
27(20 \%)\end{array}$ & $0.016^{a}$ \\
\hline \multirow{3}{*}{$\begin{array}{l}\text { How do you take the pain } \\
\text { medication? }\end{array}$} & Orally & $\begin{array}{l}\text { No } \\
\text { Yes }\end{array}$ & $\begin{array}{c}0(0 \%) \\
30(100 \%)\end{array}$ & $\begin{array}{c}6(4.4 \%) \\
130(95.6 \%)\end{array}$ & $0.118^{b}$ \\
\hline & Injections & $\begin{array}{l}\text { No } \\
\text { Yes }\end{array}$ & $\begin{array}{c}29(96.7 \%) \\
1(3.3 \%)\end{array}$ & $\begin{array}{l}112(82.4 \%) \\
24(17.6 \%)\end{array}$ & $0.023^{b}$ \\
\hline & Patches & $\begin{array}{l}\text { No } \\
\text { Yes }\end{array}$ & $\begin{array}{c}30(100 \%) \\
0(0 \%)\end{array}$ & $\begin{array}{c}125(91.9 \%) \\
11(8.1 \%)\end{array}$ & $0.033^{b}$ \\
\hline \multicolumn{2}{|c|}{ Has your pain improved as you expected with the treatment? } & $\begin{array}{l}\text { Less than expected } \\
\text { As expected } \\
\text { More than expected }\end{array}$ & $\begin{array}{c}15(48.4 \%) \\
12(38.7 \%) \\
4(12.9 \%)\end{array}$ & $\begin{array}{l}58(42.6 \%) \\
55(40.4 \%) \\
23(16.9 \%)\end{array}$ & $0.79^{\mathrm{a}}$ \\
\hline \multicolumn{2}{|c|}{$\begin{array}{l}\text { Patients that take medication for pain can easily become } \\
\text { addicted to it }\end{array}$} & $\begin{array}{c}\text { Disagree } \\
\text { Somewhat agree } \\
\text { Agree }\end{array}$ & $\begin{array}{c}10(32.3 \%) \\
4(13.9 \%) \\
17(54.8 \%)\end{array}$ & $\begin{array}{l}44(33.3 \%) \\
39(29.5 \%) \\
49(37.1 \%)\end{array}$ & $0.101^{\mathrm{a}}$ \\
\hline \multicolumn{2}{|c|}{ Medication used to treat pain leads to side effects } & $\begin{array}{c}\text { Disagree } \\
\text { Somewhat agree } \\
\text { Agree }\end{array}$ & $\begin{array}{c}5(16.1 \%) \\
6(19.4 \%) \\
20(64.5 \%)\end{array}$ & $\begin{array}{l}32(23.7 \%) \\
36(26.7 \%) \\
67(49.6 \%)\end{array}$ & $0.32^{\mathrm{a}}$ \\
\hline & & ient-related factors & & & \\
\hline Do you ever forget to & your pain medicine? & $\begin{array}{l}\text { No } \\
\text { Yes }\end{array}$ & $\begin{array}{l}21(65.6 \%) \\
11(34.4 \%)\end{array}$ & $\begin{array}{l}112(82.4 \%) \\
24(17.6 \%)\end{array}$ & $0.036^{\mathrm{a}}$ \\
\hline $\begin{array}{r}\text { Do you ever forget to } \\
\text { hours i }\end{array}$ & $\begin{array}{l}\text { ke medications at the } \\
\text { icated? }\end{array}$ & $\begin{array}{l}\text { No } \\
\text { Yes }\end{array}$ & $\begin{array}{l}20(62.5 \%) \\
12(37.5 \%)\end{array}$ & $\begin{array}{l}101(74.3 \%) \\
35(25.7 \%)\end{array}$ & $0.18^{\mathrm{a}}$ \\
\hline If you ever feel better, do $y$ & stop taking the treatment? & $\begin{array}{l}\text { No } \\
\text { Yes }\end{array}$ & $\begin{array}{c}5(16.1 \%) \\
26(83.9 \%)\end{array}$ & $\begin{array}{l}73(53.7 \%) \\
63(46.3 \%)\end{array}$ & $0.000^{\mathrm{a}}$ \\
\hline If you ever feel bad, do yc & stop taking the treatment? & $\begin{array}{l}\text { No } \\
\text { Yes }\end{array}$ & $\begin{array}{l}17(54.8 \%) \\
14(45.2)\end{array}$ & $\begin{array}{l}90(66.7 \%) \\
45(33.3 \%)\end{array}$ & $0.21^{\mathrm{a}}$ \\
\hline $\begin{array}{r}\text { If you ever feel more pain } \\
\text { than p }\end{array}$ & $\begin{array}{l}\text { o you take more medicine } \\
\text { cribed? }\end{array}$ & $\begin{array}{l}\text { No } \\
\text { Yes }\end{array}$ & $\begin{array}{c}26(81.3 \%) \\
6(18.8 \%)\end{array}$ & $\begin{array}{l}121(89.0 \%) \\
15(11.0 \%)\end{array}$ & $0.26^{\mathrm{b}}$ \\
\hline Have you stopped taking tl & medication due to its price? & $\begin{array}{l}\text { No } \\
\text { Yes }\end{array}$ & $\begin{array}{c}31(96.9 \%) \\
1(3.1 \%)\end{array}$ & $\begin{array}{c}126(92.6 \%) \\
10(7.4 \%)\end{array}$ & $0.35^{\mathrm{b}}$ \\
\hline Have you skipped a dose so & $\mathrm{t}$ the medication lasts longer? & $\begin{array}{l}\text { No } \\
\text { Yes }\end{array}$ & $\begin{array}{c}29(90.6 \%) \\
3(9.4 \%)\end{array}$ & $\begin{array}{c}129(94.9 \%) \\
7(5.1 \%)\end{array}$ & $0.39^{b}$ \\
\hline In general, you wou & say your health is ... & $\begin{array}{c}\text { Excellent or very good } \\
\text { Good } \\
\text { Normal } \\
\text { Bad }\end{array}$ & $\begin{array}{c}0(0 \%) \\
17(53.1 \%) \\
12(37.5 \%) \\
3(9.4 \%) \\
\end{array}$ & $\begin{array}{c}8(5.9 \%) \\
58(42.6 \%) \\
51(37.5 \%) \\
19(14.0 \%)\end{array}$ & $0.22^{b}$ \\
\hline & Healthcare $\mathrm{p}$ & sional- and family-relate & & & \\
\hline $\begin{array}{r}\text { The information that your } \mathrm{d} \\
\text { treatment } \mathrm{fc}\end{array}$ & $\begin{array}{l}\text { or has given you about your } \\
\text { pain was... }\end{array}$ & $\begin{array}{l}\text { Very good or good } \\
\text { Acceptable } \\
\text { Bad or very bad }\end{array}$ & $\begin{array}{c}16(50 \%) \\
12(37.5 \%) \\
4(12.5 \%)\end{array}$ & $\begin{array}{c}84(61.8 \%) \\
43(31.6 \%) \\
9(6.6 \%) \\
\end{array}$ & $0.36^{\mathrm{a}}$ \\
\hline $\begin{array}{r}\text { The attention provided by } \\
\text { pain }\end{array}$ & $\begin{array}{l}\text { our doctor regarding your } \\
\text { as ... }\end{array}$ & $\begin{array}{l}\text { Very good or good } \\
\text { Acceptable } \\
\text { Bad or very bad }\end{array}$ & $\begin{array}{c}16(50 \%) \\
10(31.3 \%) \\
6(18.8 \%)\end{array}$ & $\begin{array}{l}103(75.7 \%) \\
21(15.4 \%) \\
12(8.8 \%)\end{array}$ & $0.016^{\mathrm{a}}$ \\
\hline $\begin{array}{r}\text { Are you satisfied with the he } \\
\text { you }\end{array}$ & $\begin{array}{l}\text { received from your family for } \\
\text { ain? }\end{array}$ & $\begin{array}{c}\text { Unsatisfied } \\
\text { Satisfied } \\
\text { Very satisfied }\end{array}$ & $\begin{array}{c}8(25 \%) \\
15(46.9 \%) \\
9(28.1 \%)\end{array}$ & $\begin{array}{l}41(30.1 \%) \\
66(48.5 \%) \\
29(21.3 \%)\end{array}$ & $0.68^{\mathrm{a}}$ \\
\hline $\begin{array}{r}\text { Do you have a relative } \\
\text { your m }\end{array}$ & $\begin{array}{l}\text { at reminds you to take } \\
\text { ication? }\end{array}$ & $\begin{array}{l}\text { No } \\
\text { Yes }\end{array}$ & $\begin{array}{l}25(78.1 \%) \\
7(21.9 \%)\end{array}$ & $\begin{array}{l}103(75.7 \%) \\
33(24.3 \%)\end{array}$ & $0.77^{\mathrm{a}}$ \\
\hline
\end{tabular}

${ }^{\mathrm{a}}$ Pearson Chi-square; ${ }^{\mathrm{b}}$ Likelihood ratio; ${ }^{\mathrm{c}}$ Mann-Whitney U test. 
Related to patient factors, it is noteworthy that a high percentage of the patients self-reporting non-adherence stated that they forgot to take their medication (34.4\% vs. $17.6 \%)$; stopped the treatment when they felt better ( $83.9 \%$ vs. $46.3 \%)$ and when they felt worse $(45.2 \%$ vs. $33.3 \%)$; forgot to take the medication at the hours indicated (37.5\% vs. $25.7 \%)$; and took more medication when they felt worse $(18.8 \%$ vs. $11 \%)$. In the self-reporting adherence group, $7.3 \%$ referred to stopping taking the medication due to price, while $3.1 \%$ in the non-adherence group did so (Table 2).

Finally, the study also showed that $91.1 \%$ of the self-reported adherence group considered the attention received by the doctor to be acceptable, good or very good, while $81.3 \%$ of the non-adherent group felt the same; and $93.4 \%$ considered the information provided by the health professional to be acceptable, good or very good (versus $87.5 \%$ ), although the latter was not significant. The majority of the sample in both groups were satisfied or very satisfied with their family support $(70 \%$ and $75 \%$, respectively) (Table 2).

\section{Discussion}

This study analyzes the self-reported adherence to analgesic therapy in people with CP in Spain, and compares the outcome according to the dimensions established by the WHO. The study showed that $81.0 \%$ of the people with CP self-reported adherence to their doctor's recommendations. This data are similar to the findings in Portugal [31], where non-adherence was identified in $22.8 \%$ of the people with chronic pain conditions and different to the data from Belgium, where $48 \%$ of the patients were non-adherent to the treatment [32]. However, when we explored our findings more deeply, we found that the majority of them did not behave according to their physician's recommendations.

A possible explanation for this is that the information given to patients by their healthcare professionals is often misunderstood, carried out incorrectly, forgotten or even completely ignored. In line with these results are those published by the WHO in 2013 [33], showing than more than half of the Spanish population has inadequate or problematic health literacy levels, which is associated with poor adherence to medication [33].

Another potential explanation contributing to the high rates of self-reported adherence observed could be social desirability patterns, whereby patients feel the need to be a "good patient" so as not to be seen as negligent $[34,35]$.

In our study, nearly $20 \%$ of the participants that self-reported adherence to therapy stated that they forgot to take the medication. However, to date, forgetfulness has not been considered a determinant for medication non-adherence in patients with $\mathrm{CP}$, which may be related with the persistent presence of the unpleasant symptom [36].

The findings also show that the self-reported adherent group presented worse conditions, such as a higher intensity of the pain compared to the non-adherent group. Depending on the pathology and the intensity of pain, an individual may receive more than one drug during the course of the illness and through different administration routes, which could have an effect on adherence [15]. As shown in our study, the subjects reporting polymedication and using patches or injections more frequently self-reported adherence. This is comprehensible because these situations require more attention, more information and control by health professionals.

It is obvious that the intention to perform an action constitutes an immediate precursor to the behavior itself [37]. If patients hold beliefs that are incongruent with their doctor's prescription, or if their social group holds different points of view about their illness and treatment, patients may intentionally develop a pattern of behavior that corresponds to lack of agreement with the recommendations [38]. In fact, other studies showed that the prevalence of intentional non-adherence is higher than unintentional non-adherence [32,39]. This was reaffirmed in our study, where we found that, among patients that had self-perceived adherence, the main reason for non-adherence was intentionally stopping taking the medication when the patient felt worse or better than expected.

One important problem related to adherence is that there is no suitable standard for its evaluation in patients with CP $[10,13]$. This leads to uncertainty about the impact on clinical outcomes $[14,15]$. 
Despite this limitation, several authors report a negative correlation between adherence with analgesic therapy and pain intensity $[18,39]$, and they state that adherence reduces the costs associated with health care $[39,40]$. Other authors have reported that non-adherence undermines treatment benefits and is associated with poorer prognosis [40]. Therefore, ensuring agreement with the treatment plan is an essential part of patient care and an important objective in the optimal management of pain.

The prevalence of CP in our study was $23.5 \%$ (95\% CI: $21.0-26.2 \%)$. This is a bit higher than in another study performed in the Spanish population [4], where the prevalence was $17 \%$. This could be related to the fact that this study was performed in 2011, nearly 10 years ago, and taking into account that the prevalence of multiple chronic medical conditions is increasing worldwide [41]. Worryingly, these problems related to $\mathrm{CP}$ are expected to increase [42] because of the increase in life expectancy and aging trends in the workforce, resulting in more painful conditions, especially musculoskeletal ones [43].

Finally, some methodological limitations need to be considered in this study. The first arises with the use of a dichotomous answer to summarize self-reported adherence to therapeutic recommendations. However, adherence is widely measured as a dichotomous variable [13] in the absence of a gold standard to assess it. Moreover, we used other complementary questions to study this concept based on the dimensions established by the WHO. In the study, we analyzed patients' perceptions of adherence, and we had the opportunity to contrast their answers with other items, such as stopping taking the treatment when feeling better or due to its price. This gave us a wider view of the behavior of $C P$ sufferers, and allowed us to detect the misconceptions that led people to claim to be adherent when they were not necessarily so.

The second limitation to consider is that, since it was a population-based study and the interviews were conducted by telephone, objective methods for measuring adherence were not feasible. Furthermore, ten interviewers took part in the survey. Therefore, although a strict protocol was established to minimize discrepancies, a slight bias may have existed due to the attitude of each interviewer. Another limitation is that information about how the patients took their medication was not collected. Therefore, we could not identify if they took it on a pro re nata (prn) or "as required" basis for pain, meaning the decision of when to administer the medication is left to the patient, as circumstances required, under a previously prescribed medication regimen. It should be noted that the response rate in this study (30.5\%) was low. However, the reasons for those not responding were collected, and none of them are known to lead to bias. Furthermore, according to the literature, it is not unusual to find similar rates in these types of studies [31,44].

\section{Conclusions}

Most Spanish people with CP consider that they are adherent to their analgesic treatment. However, their behavior presents contradictions. High intensity of pain, polymedication, the administration route of the treatment (injection and patches) and some patient-related factors were associated with self-perceived adherence to treatment.

It would be advisable for professionals to inform patients about appropriate behavior regarding their therapy recommendations, and to explore potential factors related to non-adherence. This could contribute to improving pain control.

Author Contributions: I.F. conceived the idea of the article. The fieldwork was performed by de P.O.-J., H.D.S., A.S., M.D., L.D.R. and I.F. P.O.-J. performed the statistical analysis. P.O.-J. and H.D.S. were responsible for writing the manuscript. All the authors were involved in revising the content and approved the final version of the manuscript. All authors have read and agreed to the published version of the manuscript.

Funding: This research received no external funding.

Acknowledgments: The authors would like to acknowledge the effort of the interviewers who collected the data. The authors have disclosed that they have received a grant for researching in the field of pain from Fundación Española del Dolor.

Conflicts of Interest: The authors declare no conflict of interest. 


\section{References}

1. Pagé, M.G.; Fortier, M.; Ware, M.; Choinière, M. As if one pain problem was not enough: Prevalence and patterns of coexisting chronic pain conditions and their impact on treatment outcomes. J. Pain Res. 2018, 11, 237-254. [CrossRef]

2. Langley, P.C.; Ruiz-Iban, M.A.; Molina, J.T.; De Andres, J.; Castellón, J.R.G.-E.; Castellon, J.R. The prevalence, correlates and treatment of pain in Spain. J. Med. Econ. 2011, 14, 367-380. [CrossRef] [PubMed]

3. Fayaz, A.; Croft, P.; Langford, R.M.; Donaldson, L.J.; Jones, G.T. Prevalence of chronic pain in the UK: A systematic review and meta-analysis of population studies. BMJ Open 2016, 6, e010364. [CrossRef] [PubMed]

4. Dueñas, M.; Salazar, A.; Ojeda, B.; Fernández-Palacín, F.; Micó, J.A.; Torres, L.M.; Failde, I. A nationwide study of chronic pain prevalence in the general spanish population: Identifying clinical subgroups through cluster analysis. Pain Med. 2015, 16, 811-822. [CrossRef] [PubMed]

5. Ojeda, B.; Salazar, A.; Dueñas, M.; Torres, L.M.; Mico, J.A.; Failde, I. The Impact of Chronic Pain: The Perspective of Patients, Relatives, and Caregivers. Fam. Syst. Health 2014, 32, 399-407. [CrossRef] [PubMed]

6. Dueñas, M.; Ojeda, B.; Salazar, A.; Fernández-Palacín, F.; Mico, J.; Torres, L.; Failde, I. Use and satisfaction with the Healthcare System of the chronic pain patients in Spain. Result from a nationwide study. Curr. Med. Res. Opin. 2016, 32, 1813-1820. [CrossRef]

7. de Sola, H.; Salazar, A.; Dueñas, M.; Ojeda, B.; Failde, I. Nationwide cross-sectional study of the impact of chronic pain on an individual's employment. Relationship with the family and the social support. BMJ Open 2016, 6, e012246. [CrossRef]

8. Dueñas, M.; Salazar, A.; Sánchez, M.; De Sola, H.; Ojeda, B.; Failde, I. Relationship Between Using Clinical Practice Guidelines for Pain Treatment and Physicians' Training and Attitudes Toward Patients and the Effects on Patient Care. Pain Pract. 2017, 18, 38-47. [CrossRef]

9. Azevedo, L.F.; Costa-Pereira, A.; Mendonça, L.; Dias, C.C.; Castro-Lopes, J.M. Epidemiology of Chronic Pain: A Population-Based Nationwide Study on Its Prevalence, Characteristics and Associated Disability in Portugal. J. Pain 2012, 13, 773-783. [CrossRef]

10. Breivik, H.; Eisenberg, E.; O'Brien, T. The individual and societal burden of chronic pain in Europe: The case for strategic prioritisation and action to improve knowledge and availability of appropriate care. BMC Public Health 2013, 13. [CrossRef]

11. Landmark, T.; Romundstad, P.; Dale, O.; Borchgrevink, P.C.; Vatten, L.; Kaasa, S. Chronic pain: One year prevalence and associated characteristics (the HUNT pain study). Scand. J. Pain 2013, 4, 182-187. [CrossRef] [PubMed]

12. Andersson, H.I.; Ejlertsson, G.; Leden, I.; Scherstén, B. Impact of chronic pain on health care seeking, self care, and medication. Results from a population-based Swedish study. J. Epidemiol. Community Health 1999, 53, 503-509. [CrossRef] [PubMed]

13. Timmerman, L.; Stronks, D.L.; Groeneweg, J.G.; Huygen, F.J. Prevalence and determinants of medication non-adherence in chronic pain patients: A systematic review. Acta Anaesthesiol. Scand. 2016, 60, 416-431. [CrossRef] [PubMed]

14. Vrijens, B.; De Geest, S.; Hughes, D.A.; Przemyslaw, K.; Demonceau, J.; Ruppar, T.; Dobbels, F.; Fargher, E.; Morrison, V.; Lewek, P.; et al. A new taxonomy for describing and defining adherence to medications. Br. J. Clin. Pharmacol. 2012, 73, 691-705. [CrossRef] [PubMed]

15. Kardas, P.; Lewek, P.; Matyjaszczyk, M. Determinants of patient adherence: A review of systematic reviews. Front. Pharmacol. 2013, 4,1-16. [CrossRef]

16. World Health Organization (WHO). Adherence to Long-Term Therapies; Evidence for Action; WHO: Geneva, Switzerland, 2003; pp. 1-194.

17. Timmerman, L.; Stronks, D.L.; Huygen, F.J. The relation between patients' beliefs about pain medication, medication adherence and treatment outcome in chronic pain patients. Clin. J. Pain 2019, 35, 941-947. [CrossRef]

18. Stern, A.; Sánchez-Magro, I.; Rull, M. Chronic noncancer pain intensity is inversely related to analgesic adherence in pain clinics. J. Med. Econ. 2011, 14, 568-575. [CrossRef]

19. Colección Cuadernos de Población. La Población en España: 1900-2009; Fundación BBVA: Bilbao, Spain, 2010. 
20. Herr, K.A.; Mobily, P.R.; Smith, C. Depression and the experience of chronic back pain: A study of related variables and age differences. Clin. J. Pain 1993, 9, 104-114. [CrossRef]

21. Turk, D.C.; Okifuji, A.; Scharff, L. Chronic pain and depression: Role of perceived impact and perceived control in different age cohorts. Pain 1995, 4, 93-101. [CrossRef]

22. Riley, J.L.; Gilbert, G.H. Orofacial pain symptoms: An interaction between age and sex. Pain 2001, 90, $245-256$. [CrossRef]

23. Hermsen, L.A.; Leone, S.S.; van der Windt, D.A.; Smalbrugge, M.; Dekker, J.; van der Horst, H.E. Functional outcome in older adults with joint pain and comorbidity: Design of a prospective cohort study. BMC Musculoskelet. Disord. 2011, 12, 241. [CrossRef] [PubMed]

24. Miró, J.; Paredes, S.; Rull, M.; Queral, R.; Miralles, R.; Nieto, R.; Huguet, A.; Baos, J. Pain in older adults: A prevalence study in the Mediterranean region of Catalonia. Eur. J. Pain 2007, 11, 83-92. [CrossRef] [PubMed]

25. Sitio Web de Infobel España. Available online: http://eshop.infobel.com/es/productdetails.aspx?ProductID=199. (accessed on 15 January 2011).

26. Instituto Nacional de Estadística. Encuesta sobre Equipamiento y Uso de Tecnologías de la Información y Comunicación en los Hogares; Instituto Nacional de Estadística: Madrid, Spain, 2011.

27. Instituto Nacional de Estadística (INE). Patrón Municipal de 2009; Instituto Nacional de Estadística: Madrid, Spain, 2009.

28. Classification of chronic pain. Descriptions of chronic pain syndromes and definitions of pain terms. Prepared by the International Association for the Study of Pain, Subcommittee on Taxonomy. Pain. Suppl. 1986, 3, S1-S226.

29. Downie, W.W.; Leatham, P.A.; Rhind, V.M.; Wright, V.; Branco, J.A.; Anderson, J.A. Studies with pain rating scales. Ann. Rheum. Dis. 1978, 37, 378-381. [CrossRef] [PubMed]

30. Serrano, M.S.; Caballero, J.; Cañas, A.; García-Saura, P.L.; Serrano-Álvarez, C.; Prieto, J. Valoración del dolor (I). Rev. Soc. Esp. Dolor. 2002, 9, 94-108.

31. da Costa, F.A.; Pedro, A.R.; Teixeira, I.; Bragança, F.; da Silva, J.A.; Cabrita, J. Primary non-adherence in Portugal: Findings and implications. Int. J. Clin. Pharm. 2015, 37, 626-635. [CrossRef]

32. Broekmans, S.; Dobbels, F.; Milisen, K. Pharmacologic Pain Treatment in a Multidisciplinary Pain Center. Clin. J. Pain 2010, 26, 81-86. [CrossRef]

33. World Health Organization (WHO). Health literacy The solid facts. In The Solid Facts; WHO: Copenhagen, Denmark, 2013; pp. 1-68, ISBN 9789289000154.

34. Atkinson, T.M.; Rodríguez, V.M.; Gordon, M.; Avildsen, I.K.; Emanu, J.C.; Jewell, S.T.; Anselmi, K.A.; Ginex, P.K. The association between patient-reported and objective oral anticancer medication adherence measures: A systematic review. Oncol. Nurs. Forum 2016, 43, 576-582. [CrossRef]

35. Bruxvoort, K.; Festo, C.; Cairns, M.; Kalolella, A.; Mayaya, F.; Kachur, S.P.; Schellenberg, D.; Goodman, C. Measuring patient adherence to malaria treatment: A comparison of results from self-report and a customised electronic monitoring device. PLoS ONE 2015, 10, 1-18. [CrossRef]

36. Sampaio, R.; Azevedo, L.F.; Dias, C.C.; Lopes, J.M.C. Non-adherence to pharmacotherapy: A prospective multicentre study about its incidence and its causes perceived by chronic pain patients. Patient Prefer. Adherence 2020, 14, 321-332. [CrossRef]

37. Blanchard, K.A.; Morgenstern, J.; Morgan, T.J.; Labouvie, E.; Bux, D.A. Motivational subtypes and continuous measures of readiness for change: Concurrent and predictive validity. Psychol. Addict. Behav. 2003, 17, 56-65. [CrossRef] [PubMed]

38. Martin, L.R.; Williams, S.L.; Haskard, K.B.; Dimatteo, M.R. The challenge of patient adherence. Ther. Clin. Risk Manag. 2005, 1, 189-199. [PubMed]

39. Markotic, F.; Cerni Obrdalj, E.; Zalihic, A.; Pehar, R.; Hadziosmanovic, Z.; Pivic, G.; Durasovic, S.; Grgic, V.; Banozic, A.; Sapunar, D.; et al. Adherence to Pharmacological Treatment of Chronic Nonmalignant Pain in Individuals Aged 65 and Older. Pain Med. 2013, 14, 247-256. [CrossRef] [PubMed]

40. Mcdonald, H.P.; Garg, A.X.; Haynes, R.B. Interventions to Enhance Patient Adherence Scientific Review. JAMA 2002, 288, 2868-2879. [CrossRef] [PubMed]

41. Assadeck, H.; Toudou, M.; Hassane, F.; Douma, D.; Adehossi, E. Prevalence and characteristics of chronic pain: Experience of Niger. Scand. J. Pain 2017, 17, 252-255. [CrossRef] [PubMed] 
42. Cheung, C.W.; Choi, S.W.; Wong, S.S.C.; Lee, Y.; Irwin, M.G. Changes in Prevalence, Outcomes, and Help-seeking Behavior of Chronic Pain in an Aging Population Over the Last Decade. Pain Pract. 2017, 17, 643-654. [CrossRef] [PubMed]

43. Shaw, W.S.; Besen, E.; Pransky, G.; Boot, C.R.L.; Nicholas, M.K.; McLellan, R.K.; Tveito, T.H. Manage at work: A randomized, controlled trial of a self-management group intervention to overcome workplace challenges associated with chronic physical health conditions. BMC Public Health 2014, 14, 515. [CrossRef]

44. Broekmans, S.; Dobbels, F.; Milisen, K.; Morlion, B.; Vanderschueren, S. Determinants of medication underuse and medication overuse in patients with chronic non-malignant pain: A multicenter study. Int. J. Nurs. Stud. 2010, 47, 1408-1417. [CrossRef]

Publisher's Note: MDPI stays neutral with regard to jurisdictional claims in published maps and institutional affiliations.

(C) 2020 by the authors. Licensee MDPI, Basel, Switzerland. This article is an open access article distributed under the terms and conditions of the Creative Commons Attribution (CC BY) license (http://creativecommons.org/licenses/by/4.0/). 